\title{
First-Principles Model to Evaluate Quantitatively the Long-Life Behavior of Cellulose Acetate Polymers
}

\author{
Abeer Al Mohtar, ${ }^{* a}$ Sofia Nunes, ${ }^{\mathrm{b}}$ Joana Silva, ${ }^{\mathrm{b}}$ Ana Maria Ramos, ${ }^{\mathrm{b}}$ João Lopes ${ }^{\mathrm{c}}$ and Moisés L. Pinto ${ }^{\text {*a }}$ \\ ${ }^{a}$ CERENA, Departamento de Engenharia Química, Instituto Superior Técnico, Universidade de Lisboa, 1049-001 Lisboa, \\ Portugal. E-mail: abeer.mohtar@tecnico.ulisboa.pt and moises.pinto@tecnico.ulisboa.pt \\ bLAQV-REQUIMTE, Departamento de Conservação e Restauro, Faculdade de Ciências e Tecnologia, Universidade NOVA \\ de Lisboa, 2829516 Monte De Caparica, Portugal \\ ciMED.Ulisboa, Faculdade de Farmácia, Universidade de Lisboa, Av. Prof. Gama Pinto, 1649-003 Lisboa, Portugal \\ This document provides supplementary information to "First-Principles Model to Evaluate Quantitatively the Long-Life Behavior \\ of Cellulose Acetate Polymers". In the main article, we presented the Henry's law constants for AA on CDA films. Here we present \\ the experimental results and the justification of the linear dependence. We present the dependence of $\mathrm{K}_{\mathrm{H}}$ on temperature and aging \\ of the polymer. More details on the data fitting of the dependence of water concentration on temperature, relative humidity and $\mathrm{pH}$ \\ are presented as well.
}

\section{Table of contents}

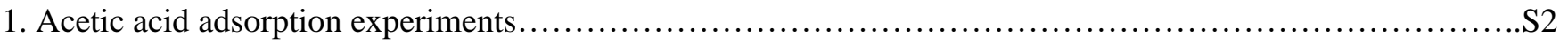

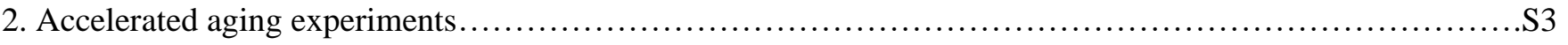

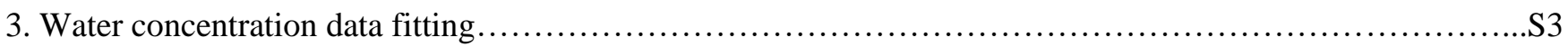

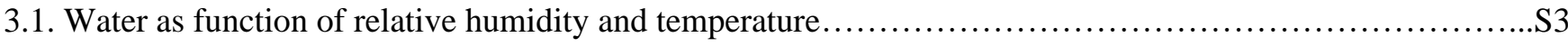

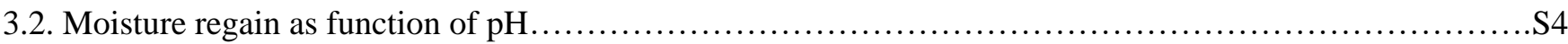

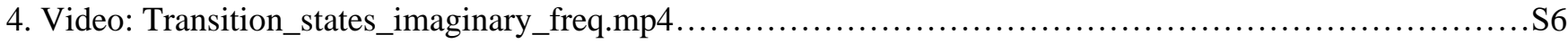

\section{List of Figures}

Figure S1. (a) Adsorption isotherm setup, equipped with a microbalance, pressure sensor and a water bath, and (b) Acetic acid isotherms at $T=25^{\circ} \mathrm{C}$ and $T=70{ }^{\circ} \mathrm{C}$, the adsorbed number of moles of AA per gram of CDA is plotted (a) versus $p / p^{0}$

Figure S2. (a) Acetic acid isotherms at $T=25{ }^{\circ} \mathrm{C}$ and $T=70{ }^{\circ} \mathrm{C}$, the adsorbed number of moles of AA per gram of $\mathrm{CDA}$ is plotted versus the concentration of AA in the chamber, and (b) Acetic acid isotherms at $T=25^{\circ} \mathrm{C}$ for nonaged new CDA polymer and that of CDA aged of minus $10 \%$

DS.

Figure S3. Film representative of the degradation's heterogeneity. CDA acid catalyzed degradation experiment,

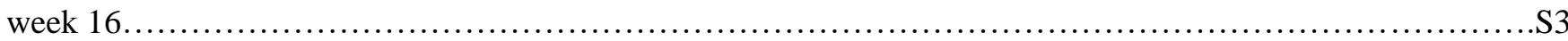

Figure S4. Moisture regain as function of $\mathrm{pH}$, the reported data are presented along with the best fit............S4

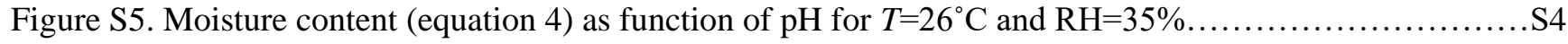




\section{List of tables}

Table S.1. Tabulated data from Figure 6. "Effect of temperature on moisture equilibrium curve of $35 \mathrm{~mm}$ color motion picture film on cellulose triacetate base", from Adelstein et al. paper...............................S3

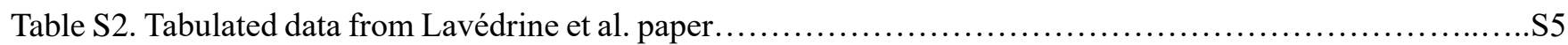

\section{ACETIC ACID ADSORPTION EXPERIMENTS}

Adsorption isotherms of acetic acid were measured using a microbalance system shown in Figure S1(a). About 50 $\mathrm{mg}$ of polymer is used for each experiment. The samples were outgassed for about 30 minutes. Small amounts of AA were injected after purification with freeze-vacuum-thaw cycles inside a vacuum cell. The injection of AA was done through controlled evaporation via the yellow valve shown in Figure S1 (a). At room temperature, with closed valve, the vapor and liquid phases of AA inside the veil are at equilibrium. The microbalance system is under high vacuum $\left(10^{-6} \mathrm{mbar}\right)$. When the valve is open, AA will start evaporating into the chamber, the pressure sensor reads the pressure indicating the amount of AA in the chamber, when the required amount is reached the valve is closed and the system is left to attain equilibrium. Extension rods and the pan of the microbalance were chosen to be made of silica so that we have least interaction with AA and two symmetrical pans are used in each side. Moreover, the region of pressure used (less than one tenth of saturation pressure) no condensation droplets are expected on the walls of the microbalance. The mass increase was recorded at equilibrium (via the microbalance - CI electronics) as function of the pressure (via MKS a-BARATRON capacitance manometer, 10 Torr-range) of AA at equilibrium. The temperature was kept constant with a water bath (VMR, VWB2 series, temperature stability $0.2{ }^{\circ} \mathrm{C}$ ). Figure $\mathrm{S} 1$ (b) presents the experimental measurements along with the best fits for $T=25{ }^{\circ} \mathrm{C}$ and $T=70{ }^{\circ} \mathrm{C}$. Low concentrations of AA were used since it represents the practical conditions of interest. For this region, a linear relation between the concentration of AA inside the polymer and that in the atmosphere is noticed and thus can be fitted to the linear Henry's law. Plotting the adsorbed amounts of AA per gram of CDA as function of relative pressure no temperature dependence of the Henry's law constant is observed. This could be explained by the fact that this dependence is accounted for in the saturation pressure. While plotting this quantity as function of concertation of AA in the atmosphere (Figure S2(a)) a dependence of Henry's law constant on temperature is observed. These two Henry's law constants are reported in different units and care should be taken when applying these constants in other equations. 
(a)

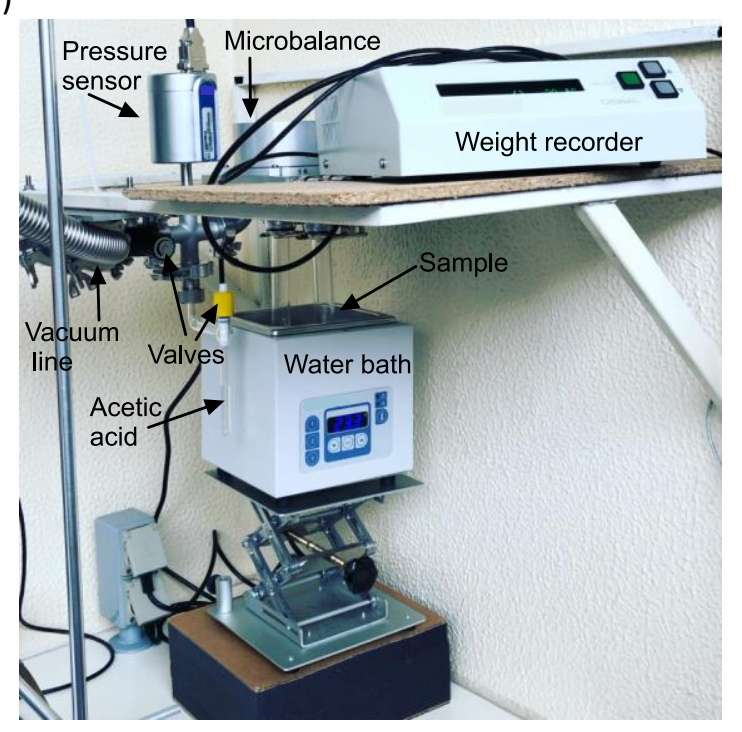

(b)

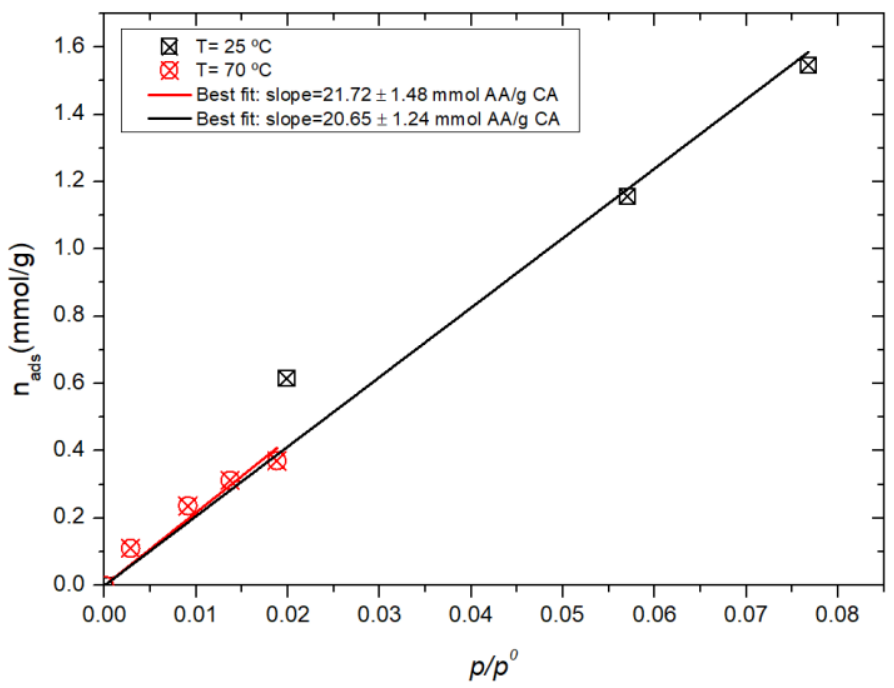

Figure S1. (a) Adsorption isotherm setup, equipped with a microbalance, pressure sensor and a water bath, and (b) Acetic acid isotherms at $T=25^{\circ} \mathrm{C}$ and $T=70{ }^{\circ} \mathrm{C}$, the adsorbed number of moles of AA per gram of CDA is plotted versus $p / p^{0}$. To see the effect of aging on the Henry's law constant, AA sorption isotherm measurements were performed on an aged film. The choice of the film was slightly aged film (minus $10 \%$ of DS) since this stage is the most critical one. Figure S2 (b) Shows that the experimental results of AA adsorption isotherm of new and slightly aged films. From the results and correspond fit we consider any alteration of the Henry's law constant at this stage of degradation.
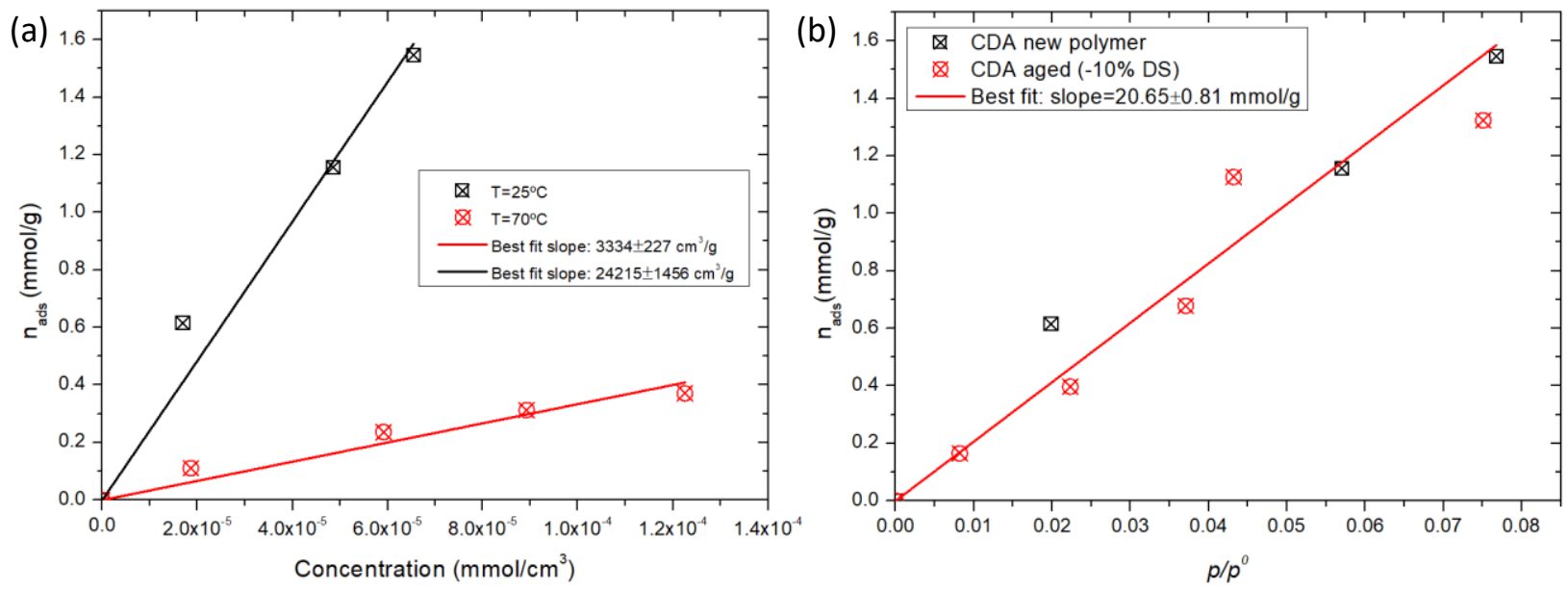

Figure S2. (a) Acetic acid isotherms at $T=25^{\circ} \mathrm{C}$ and $T=70^{\circ} \mathrm{C}$, the adsorbed number of moles of AA per gram of CDA is plotted versus the concentration of AA in the chamber, and (b) Acetic acid isotherms at $T=25^{\circ} \mathrm{C}$ for non-aged new CDA polymer and that of $\mathrm{CDA}$ aged of minus $10 \%$ DS.

\section{ACCELERATED AGING EXPERIMENTS}

Figure S3 provides a visual assessment of the non-homogenous degradation taking place at relatively advanced degradation stages (week 16) giving rise to an increased standard deviation. 


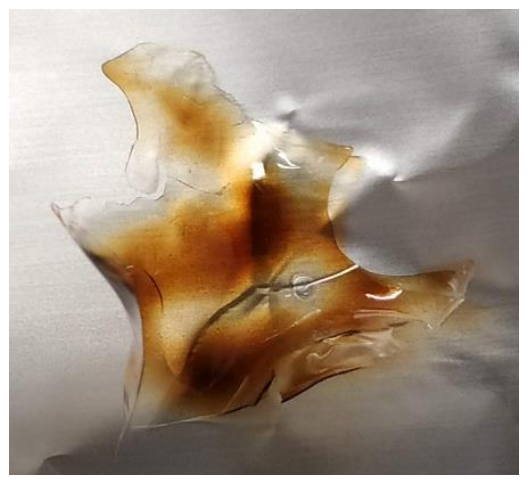

Figure S3. Film representative of the degradation's heterogeneity. CDA acid catalyzed degradation experiment, week 16.

\section{WATER CONCENTRATION DATA FITTING}

\subsection{Water as function of relative humidity and temperature:}

The moisture content, as weight percentage, for cellulose triacetate color motion picture films as function of relative humidity and temperature is reported by Adelstein et al. ${ }^{\mathrm{S}}$. The reported data are tabulated in table S.1. The Matlab curve fitting toolbox was used to fit the data to two independent variables ( $\mathrm{cftool}(\mathrm{x}, \mathrm{y}, \mathrm{z})$ ), with $x, y$ vectors are the relative humidity (\%) and temperature (K) respectively, and $z=2$-Dimensional matrix of data (Table S1).

The obtained function is:

$$
\text { Moisture content }(\%)=4.251+0.0488 \times \mathrm{RH}-0.0125 \times T
$$


Table S1. Tabulated data from Figure 6. "Effect of temperature on moisture equilibrium curve of 35 mm color motion picture film on cellulose triacetate base", from Adelstein et al. report.

\begin{tabular}{|c|c|c|c|c|c|}
\hline & $60^{\circ} \mathrm{C}$ & $40^{\circ} \mathrm{C}$ & $20^{\circ} \mathrm{C}$ & $5^{\circ} \mathrm{C}$ & $-16^{\circ} \mathrm{C}$ \\
\hline $\mathrm{RH}(\%)$ & $\begin{array}{c}\text { moisture content } \\
(\%)\end{array}$ & $\begin{array}{c}\text { moisture content } \\
(\%)\end{array}$ & $\begin{array}{c}\text { moisture content } \\
(\%)\end{array}$ & $\begin{array}{c}\text { moisture content } \\
(\%)\end{array}$ & $\begin{array}{c}\text { moisture content } \\
(\%)\end{array}$ \\
\hline 24.39 & 1.42 & 1.46 & 1.66 & 1.92 & 2.12 \\
\hline 25.93 & 1.49 & 1.55 & 1.77 & 1.99 & 2.17 \\
\hline 27.48 & 1.58 & 1.67 & 1.87 & 2.05 & 2.22 \\
\hline 29.72 & 1.7 & 1.79 & 1.98 & 2.12 & 2.29 \\
\hline 31.96 & 1.82 & 1.93 & 2.06 & 2.2 & 2.37 \\
\hline 33.92 & 1.9 & 2.03 & 2.12 & 2.27 & 2.46 \\
\hline 36.44 & 2 & 2.11 & 2.22 & 2.37 & 2.59 \\
\hline 40.93 & 2.16 & 2.26 & 2.4 & 2.61 & 2.96 \\
\hline 44.71 & 2.28 & 2.37 & 2.62 & 2.89 & 3.34 \\
\hline 49.19 & 2.39 & 2.62 & 2.91 & 3.33 & 3.62 \\
\hline 51.99 & 2.49 & 2.8 & 3.1 & 3.53 & 3.78 \\
\hline 54.37 & 2.6 & 2.95 & 3.27 & 3.67 & 3.87 \\
\hline 56.47 & 2.72 & 3.08 & 3.38 & 3.77 & 3.95 \\
\hline 59.28 & 2.87 & 3.26 & 3.53 & 3.88 & 4.04 \\
\hline 62.22 & 3.03 & 3.4 & 3.67 & 3.97 & 4.1 \\
\hline 65.72 & 3.22 & 3.57 & 3.81 & 4.04 & $\mathrm{NaN}$ \\
\hline 68.53 & 3.41 & 3.69 & 3.91 & 4.08 & $\mathrm{NaN}$ \\
\hline 71.05 & 3.5 & 3.78 & 3.99 & $\mathrm{NaN}$ & $\mathrm{NaN}$ \\
\hline 73.15 & 3.61 & 3.86 & 4.04 & $\mathrm{NaN}$ & $\mathrm{NaN}$ \\
\hline 75.81 & 3.71 & 3.94 & 4.09 & $\mathrm{NaN}$ & $\mathrm{NaN}$ \\
\hline 78.2 & 3.84 & 4.02 & $\mathrm{NaN}$ & $\mathrm{NaN}$ & $\mathrm{NaN}$ \\
\hline 79.46 & 3.9 & 4.06 & $\mathrm{NaN}$ & $\mathrm{NaN}$ & $\mathrm{NaN}$ \\
\hline 81.84 & 3.98 & $\mathrm{NaN}$ & $\mathrm{NaN}$ & $\mathrm{NaN}$ & $\mathrm{NaN}$ \\
\hline 84.5 & 4.07 & $\mathrm{NaN}$ & $\mathrm{NaN}$ & $\mathrm{NaN}$ & $\mathrm{NaN}$ \\
\hline 85.9 & 4.12 & $\mathrm{NaN}$ & $\mathrm{NaN}$ & $\mathrm{NaN}$ & $\mathrm{NaN}$ \\
\hline
\end{tabular}

\subsection{Moisture regain as function of $\mathrm{pH}$ :}

The moisture regain data are reported in literature as percentage by weight of the original polymer ${ }^{\mathrm{S} 2}$. The data used in the current model are the ones reported for cellulose triacetate films which had been stored under archival conditions $\left(5{ }^{\circ} \mathrm{C}\right.$ and $15-40 \% \mathrm{RH}$ ), since they showed to be more consistent. Figure S4 presented the used data along with the best fit:

$$
\text { moisture regain }(\%)=7.2 \times 10^{11} \mathrm{pH}^{-20.29}+1.16 \text {. }
$$




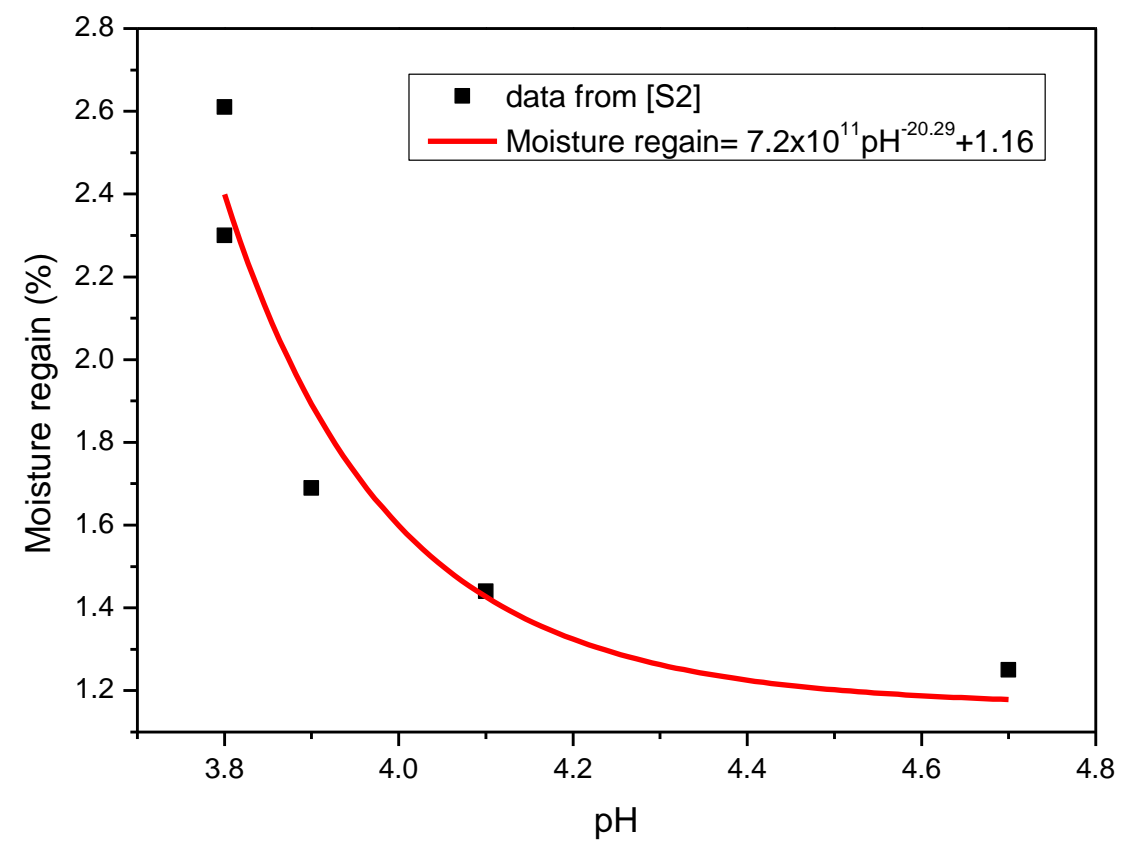

Figure S4. Moisture regain as function of $\mathrm{pH}$, the reported data are presented along with the best fit.

However, Edge et al. ${ }^{\mathrm{S} 2}$ calculate the moisture retention due to the increased acidity by putting the film in the oven for two hours at temperature $\left(100-105{ }^{\circ} \mathrm{C}\right)$, this leads to the evaporation of the acquired moisture along with some original moisture content. For a new film with a $\mathrm{pH}$ of 6-7 no water retention is expected thus the offset of $1.16 \%$ corresponds to the original moisture content leaving the film. The moisture retention due to increased acidity is represented by the first part of the equation. Thus, adding the effect of $\mathrm{pH}$ on water retention to equation (S1) we get:

$$
\begin{aligned}
& \text { Moisture content }(\%)=4.251+0.0488 \times R H-0.0125 \times T+7.2 \times \\
& 10^{11} \mathrm{pH}^{-20.29}
\end{aligned}
$$

In a separate study performed by Lavédrine et al. ${ }^{\mathrm{S} 3}$, water content was measured for CTA-based films preconditioned at $T=26{ }^{\circ} \mathrm{C}$ and relative humidity $35 \%$, as function of degradation state of the film. They obtained the results shown in table S2. Plotting equation (S3) for the same temperature and relative humidity conditions as function of $\mathrm{pH}$ (6-3.5 range) Figure $\mathrm{S} 5$ is obtained. In the referred study they do not directly measure the $\mathrm{pH}$ of the films. However, the indications given in Table S2 are in line with the moisture content obtained by equation S3. 
Table S2. Tabulated data from Lavédrine et al. paper.

\begin{tabular}{|l|l|}
\hline Film state & Water content \\
\hline New film & $2.1 \%$ \\
\hline Old film, good condition & $2.3-2.61 \%$ \\
\hline Vinegar syndrome "more acidic" & $4.55 \%$ \\
\hline
\end{tabular}

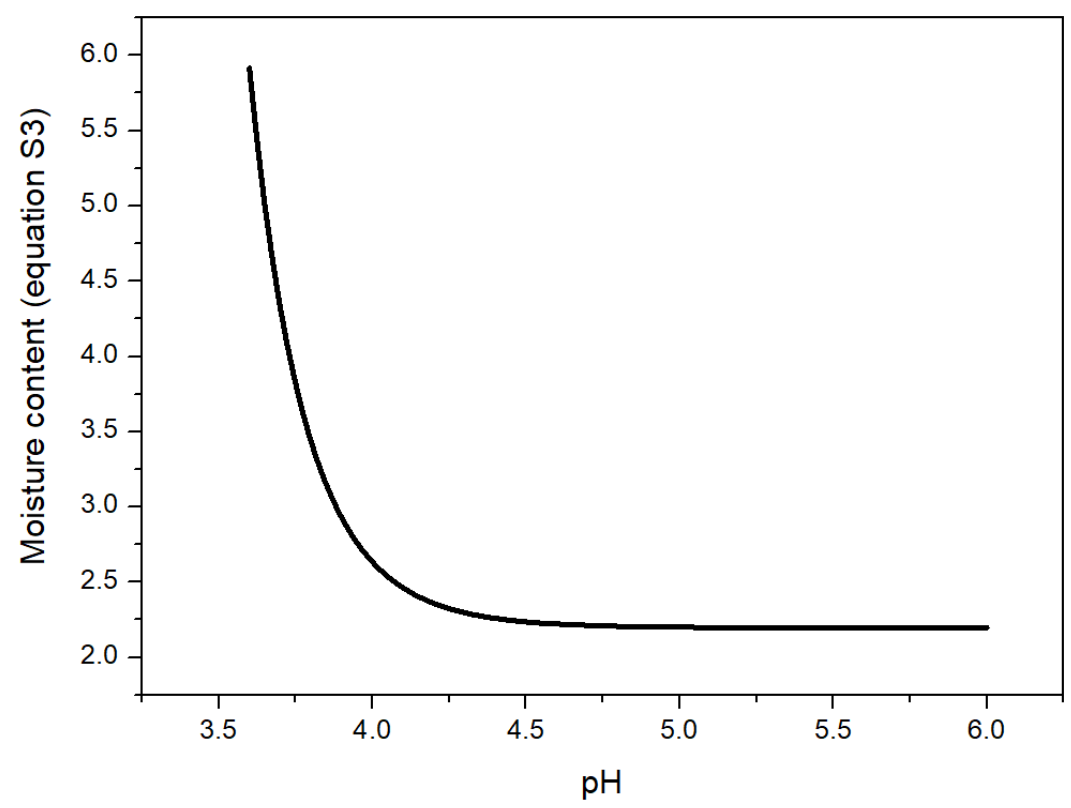

Figure S5. Moisture content (equation 4) as function of $\mathrm{pH}$ for $\mathrm{T}=26^{\circ} \mathrm{C}$ and $\mathrm{RH}=35 \%$

In the developed model the unit of concentration used is $\mathrm{mmol} / \mathrm{g}$, thus equations $\mathrm{S} 1$ and $\mathrm{S} 2$ units are converted according to equation $\mathrm{S} 4$ :

$$
\begin{aligned}
& \mathrm{C}_{\text {water }}\left(\frac{\mathrm{mmol}_{\mathrm{H}_{2} \mathrm{O}}}{\mathrm{g}_{\text {polymer }}}\right)=\mathrm{C}_{\text {water }}(\%)\left(\frac{\mathrm{g} \mathrm{H}_{2} \mathrm{O}}{100 \text { g polymer }^{\prime}}\right) \times \frac{1}{\mathrm{M}_{\mathrm{H}_{2} \mathrm{O}}}= \\
& \mathrm{C}_{\text {water }}(\%)\left(\frac{\mathrm{g} \mathrm{H}_{2} \mathrm{O}}{100 \text { g polymer }}\right) \times \frac{1000}{18.05}\left(\frac{\mathrm{mmol}_{\mathrm{H}_{2} \mathrm{O}}}{\mathrm{g}_{\mathrm{H}_{2} \mathrm{O}}}\right)=0.555 \times \\
& \mathrm{C}_{\text {water }}(\%)\left(\frac{\text { mmol }_{\mathrm{H}_{2} \mathrm{O}}}{\mathrm{g}_{\text {polymer }}}\right) .
\end{aligned}
$$

Upon multiplying equation $\mathrm{S} 3$ by a factor of 0.55 , equation 5 is obtained.

\section{Video:Transition_states_imaginary_freq.mp4}

This video shows the transition state imaginary frequency of the first and second reaction steps for the deacetylation under neutral conditions as well as that under acid-catalyzed deacetylation. 


\section{REFERENCES}

(1) Adelstein, P. Z.; Bigourdan, J.-L.; Reilly, J. M. Moisture Relationships of Photographic Film. J. Am. Inst. Conserv. 1997, 36 (3), 193. https://doi.org/10.2307/3179948.

(2) Allen, N. S.; Edge, M.; Rorie, C. V.; Jewitt, T. S.; Appleyard, J. H. The Degradation and Stabilization of Historic Cellulose Acetate/Nitrate Base Motion-Picture Film. J. Photogr. Sci. 1988, 36 (3), 103-106. https://doi.org/10.1080/00223638.1988.11736978.

(3) Lavédrine, B., Borenstein, D., Dubail, M., Furdygiel, B., Garnier, C., Gillet, M., Langlois G., Thi-Phuong N., Rakotonirainy, M. S. Biocontamination at the French Film Archives: Study of Its Origin and Its Remediation.; Indiana University Press, 2017. 